\title{
Detection of Aflatoxin M1 in Pasteurized Canned Milk and Using of UV Radiation for Detoxification
}

\author{
${ }^{1}$ Fadia Falah Hassan, ${ }^{2}$ Halima Zugher Hussein
}

\begin{abstract}
The current study was designed to investigate the presence of aflatoxin M1 in 25 samples of pasteurized canned milk which collected randomly from some Iraqi local markets using ELISA technique. Aflatoxin M1 was present in 21 samples, the concentration of aflatoxin M1 ranged from (0.25-50 ppb).

UV radiation ( $365 \mathrm{~nm}$ wave length) was used for detoxification of aflatoxin M1 (sample with highest concentration $/ 50 \mathrm{ppb}$ of aflatoxin M1 in two different volumes $((25 \& 50 \mathrm{ml}))$ for two different time (15 \& $30 \mathrm{~min}$ ) and $30,60,90 \mathrm{~cm}$ distance between lamp and milk layer were used for this purpose). Results showed that distance between lamp and milk layer was the most effective parameter in reduction of aflatoxin $\mathrm{M} 1$, and whenever the distance increase the effect also increase.
\end{abstract}

Keywords- Aflatoxin M1, detection, Milk, UV radiation, Detoxification

\section{INTRODUCTION}

Mycotoxins are secondary metabolites produced by various fungi [1]. Aflatoxins are fungal metabolites produced by three species of Aspergillus, namely A. flavus, A. parasiticus and A. nomius. A. flavus produces only B aflatoxins, while the other two species produce both $B$ and $G$ aflatoxins. One of the mycotoxins, aflatoxin M1 (AFM1) is the hydroxylated metabolite of aflatoxin B1 (AFB1) and can be found in milk and subsequently in other dairy products when lactating animals are fed with contaminated feedstuffs [2].

About 1-2\% of aflatoxin B1 in animals feed is transformed to AFM1 in milk, it may vary from animal to animal. 12-24 h after the first aflatoxin B1 ingestion, the toxin can be detected in the milk [3].

The occurrence of aflatoxin M1 in milk is transitory in nature and reaches maximum within two days after the intake of the contaminated commodity [4]. Aflatoxins represent a serious risk for animal and human health, especially for children, who are the major milk consumers [5].The hepatotoxic, genotoxic, carcinogenic, teratogenic, immunosuppressive and antinutritional effects of aflatoxins are well documented [6].

\footnotetext{
${ }^{1}$ Fadia Falah Hassan: Department of Biology, College of education for pure, ciences ( Ibn- Al- haitham), Baghdad University, IRAQ.

${ }^{2}$ Halima Zugher Hussein is with the Department of Plant protection, College of Agriculture, Baghdad University,IRAQ
}

Aflatoxins are considered to be human liver carcinogens, Aflatoxin B1 being the most potent. Aflatoxin M1 has a potency approximately one order of magnitude lower than that of aflatoxin B1 [7]. The presence of aflatoxin M1 in milk and dairy products can be a potential threat to the health of consumers [8]. Exposure to aflatoxin M1 through milk products is a serious problem for public health. Several countries have established regulatory limits for aflatoxin M1 in raw milk and milk products, which vary from country to country [9].

At present, aflatoxin presence in feed, milk and dairy products can be systematically controlled in Europe and other developed countries [10]. The European Community has set the maximum permitted level for aflatoxin M1 in raw milk and heat-treated milk at $0.05 \mu \mathrm{g} \mathrm{L}-1$ [11]. Various physical, chemical and biological agents have been used to detoxify aflatoxins from food and feed materials [12]. However, no universally applicable, effective and practical methods are currently available [13]. Ultraviolet (UV) energy can be used effectively to inactivate aflatoxin M 1 in milk [14]. UV irradiation has been discovered for many years as an effective physical method to destroy aflatoxins for its photosensitive property [15] .Rate of degradation was a function of the film thickness and depth of penetration of the rays when operating conditions were held constant [16]. Because aflatoxins are photosensitive [15], our aim was to study the detection of aflatoxin M1 and detoxification of it in milk using ultraviolet (UV) energy at different distance between UV source and milk and different volumes of milk at different times.

\section{A. Samples collection:}

\section{MATERIAL AND METHODS}

Twenty five sample of liquid canned milk were randomly collected from some Iraqi local markets which Listed in the following table-1:

Detection of aflatoxin M1 in milk samples using Enzyme Linked Immune Sorbent Assay (ELISA) technique:

Detection of aflatoxin M1 by ELISA technique was performed using ELISA kit which supplied from Shenzhen Lvshiyuan Biotechnology company.

Determination of aflatoxin $M 1$ concentration:

The concentration \% of aflatoxin M1 in test samples was calculated using aflatoxin M1 standard curve according to the following equation:

Percentage of absorbance value $=\mathrm{B} / \mathrm{BO} \times 100 \%$ $\mathrm{B}=$ the average OD value of the sample or the standard solution.

$\mathrm{B} 0=$ the average $\mathrm{OD}$ value of the $0 \mathrm{ng} / \mathrm{ml}$ standard solution. Irradiation of samples 
TABLE I

DIFFERENT MILK SAMPLES WITH THEIR ORIGIN

\begin{tabular}{|l|l|}
\hline \multicolumn{1}{|c|}{ Milk brand } & \multicolumn{1}{c|}{ Origin } \\
\hline KDD full cream & Kuwait \\
\hline KDD half cream & Kuwait \\
\hline KDD light cream & Kuwait \\
\hline KDD skimmed & Kuwait \\
\hline Süt aysah & Turkey \\
\hline Alsafi low fat & Saudi Arabia \\
\hline Almarai full cream & Saudi Arabia \\
\hline Almarai half cream & Saudi Arabia \\
\hline Almarai light cream & Saudi Arabia \\
\hline Almarai skimmed & Saudi Arabia \\
\hline Nada full cream & Saudi Arabia \\
\hline Nada half cream & Saudi Arabia \\
\hline Nada light cream & Saudi Arabia \\
\hline Nadec full cream & Saudi Arabia \\
\hline Nadec half cream & Saudi Arabia \\
\hline Nadec light cream & Saudi Arabia \\
\hline Pinar & Turkey \\
\hline Milky way & Egypt \\
\hline Mars & Egypt \\
\hline Juda & Kuwait \\
\hline AL Rai & Saudi Arabia \\
\hline Hammoudeh Banana flavor & Jordan \\
\hline Safio strawberry flavor & Saudi Arabia \\
\hline Safio Banana flavor & Saudi Arabia \\
\hline YAG GO vanilla flavor & France \\
\hline
\end{tabular}

\section{Ultraviolet source}

The source of UV energy was a UV lamp (VISION science Co., Ltd, Korea), the main wavelength of the Lamp was 365 $\mathrm{nm}$. The lamp was elevated to give a distance between lamp and milk layer of $(30,60,90 \mathrm{~cm})$ respectively.

\section{UV Treatment:}

Different volumes of contaminated milk sample (sample with highest concentration $/ 50 \mathrm{ppb})(25 \mathrm{~mL} \& 50 \mathrm{~mL})$ was exposed to UV radiation $(365 \mathrm{~nm})$ for $(15 \& 30 \mathrm{~min})$ and the residual aflatoxin $\mathrm{M} 1$ content was measured at the end of each exposure.

\section{Statistical analysis}

All analytical determinations were performed at least in triplicate using SPSS program v 11.5. Values of different parameters were expressed as the mean \pm standard error using student T-test. A defferences of $\mathrm{P} \leq 0.05$ was considered statistically significant.

\section{RESULTS AND DISCUSSION:}

Detection of aflatoxin M1 in milk samples using Enzyme Linked Immune Sorbent Assay (ELISA) technique:

Our results showed that twenty one samples of milk were contained aflatoxin M1, and the concentration of aflatoxin M1 ranged from $0.25 \mathrm{ppb}$ to $50 \mathrm{pbb}$, table-2.
TABLE II

QuantiTative Detrmination Of Aflatoxin M1 In Some MilK COLLECTED SAMPLES USING INDIRECT ELISA TECHNIQU.

\begin{tabular}{|l|l|}
\hline \multicolumn{1}{|c|}{ Milk samples } & $\begin{array}{c}\text { Aflatoxin M1 } \\
\text { concentration / ppb }\end{array}$ \\
\hline KDD full cream & 16.25 \\
\hline KDD half cream & 13.75 \\
\hline KDD light cream & 5 \\
\hline KDD skimmed & 0 \\
\hline Süt aysah & 5.5 \\
\hline Alsafi low fat & 15 \\
\hline Almarai full cream & 5 \\
\hline Almarai half cream & 2.5 \\
\hline Almarai light cream & 5 \\
\hline Almarai skimmed & 10 \\
\hline Nada full cream & 25 \\
\hline Nada half cream & 50 \\
\hline Nada light cream & 37.5 \\
\hline Nadec full cream & 50 \\
\hline Nadec half cream & 5.5 \\
\hline Nadec light cream & 11.25 \\
\hline Pinar & 6.25 \\
\hline Milky way & 0 \\
\hline Mars & 0 \\
\hline Juda & 12.5 \\
\hline AL Rai & 5 \\
\hline Hammoudeh Banana flavor & 12.5 \\
\hline Safio strawberry flavor & 0 \\
\hline Safio Banana flavor & 2.5 \\
\hline YAG GO vanilla flavor & 0.25 \\
\hline
\end{tabular}

Results of the present study show that the concentration of aflatoxin $\mathrm{M} 1$ in examined milk samples ranged from $0.25 \mathrm{ppb}$ to $50 \mathrm{ppb}$, others studies have been conducted in other countries in this context. [17] determined the level of aflatoxin M1 in milk samples ranging from 0.001 to $0.0235 \mathrm{ppb}$. In a study conducted by [18], the mean of Aflatoxin M1 in pasteurized milk was 0.019 ppb. [19] examined 122 samples for aflatoxin M1 and reported that the mean concentration of aflatoxin M1 was $0.04 \mathrm{ppb}$. [20] investigated 85 pasteurized milk samples were analyzed for aflatoxin M1 with the ELISA technique. Seventy-five samples were found to be contaminated with aflatoxin M1and the range of aflatoxin M1 was (27-48 ppb), While [21] revealed that the level of aflatoxin M1 ranging from 0.001 to 0.117 ppb. [22] measured aflatoxin M1in pasteurized milk samples from the School Milk Project in Thailand and The highest concentration of aflatoxin M1 found in school milk samples was $0.114 \mathrm{ppb}$, whereas [23] revealed that the range of aflatoxin M1 in pasteurized milk ranging from (0.023-0.154 ppb).

U.S Food and Drug Administration (FDA) was determined the action levels of aflatoxin M1 in milk (0.5ppb) [24].

According to FDA's action levels for aflatoxin M1 in milk and when compared with our results, we can conclude disqualification of the most of milk samples for human consumption due to the concentration of aflatoxin M1 in these samples which exceeded the allowable limit. Detoxification of aflatoxin M1 from milk using UV light. The results of our study is mention in the following table-3: 
TABLE III

EFFICIENCY VARIATION OF DETOXIFECATION OF AFLATOXIN M1AT DiFFERENT DisTANCES BETWEEN LAMP AND MILK LAYER, TIME OF Exposure ANd Volume OF Milk SAmple (Milk SAMPLE Was Chosen IN 50 PPB CONCENTRATION)

\begin{tabular}{|l|l|l|l|}
\hline $\begin{array}{c}\text { Distances } \\
\text { between } \\
\text { lamp and } \\
\text { milk layer } \\
(\mathrm{cm})\end{array}$ & $\begin{array}{c}\text { Time of } \\
\text { exposure } \\
(\mathrm{min})\end{array}$ & $\begin{array}{c}\text { Volume } \\
\text { of milk } \\
\text { sample } \\
(\mathrm{ml})\end{array}$ & $\begin{array}{c}\text { Concentration of } \\
\text { aflatoxin M1(ppb) } \\
\text { (Each value expressed } \\
\text { as Mean } \pm \text { Standard } \\
\text { Error (SE) of three } \\
\text { replicates }\end{array}$ \\
\hline 30 & 15 & 25 & 17.5 \\
\hline 30 & 15 & 50 & 12.5 \\
\hline 30 & 30 & 25 & 17.5 \\
\hline 30 & 30 & 50 & 15 \\
\hline 60 & 15 & 25 & 15 \\
\hline 60 & 15 & 50 & $0.5 *$ \\
\hline 60 & 30 & 25 & 0 \\
\hline 60 & 30 & 50 & 0 \\
\hline 90 & 15 & 25 & 13.75 \\
\hline 90 & 15 & 50 & 0 \\
\hline 90 & 30 & 25 & 0 \\
\hline 90 & 30 & 50 & 0 \\
\hline
\end{tabular}

$*=$ Significant $(\mathrm{P} \leq 0.05)$

From the results that mention in the table above we can observe efficiency of UV light to reduce the aflatoxin M1 from contaminated milk.

Three data were used in our experiment (distances between lamp and milk layer, time of exposure and volume of milk sample). Distance between lamp and milk layer was the most effective parameter in our test, and three distances were used $(30,60$ and $90 \mathrm{~cm})$. Results shows that $90 \mathrm{~cm}$ distance was more effective, and whenever the distance increase the effect also non-significantly increase, also the other two parameters (time of exposure and volume of milk sample) were effective in reduction of aflatoxin M1 from milk but less than distance parameter.

\section{ACKNOWLEDGMENTS}

Worm thanks and appreciate go to the staff of the (Department of Biology, college of education for pure science/ Ibn- Alhaithum / Baghdad university), in Iraq, for their support in completing this work.

\section{REFERENCES}

[1] M. Schmidt-Heydt and R. Geisen. "A microarray for monitoring the production of mycotoxins in food". International Journal of Food Microbiology,2007,117(2): 131-140. https://doi.org/10.1016/j.ijfoodmicro.2007.01.014

[2] A. Prandini, G. Tansini, S. Sigolo, L. Filippi, M. Laporta, and G. Piva. "On the occurrence of aflatoxin M1 in milk and dairy products". Food and Chemical Toxicology, 2009, 47(5): 984-991. https://doi.org/10.1016/j.fct.2007.10.005

[3] R.Ebrahim. " A Study on Contamination of Alatoxin M1 in milk and Infant milk Products in Iran". American-Eurasian Journal of Toxicological Sciences, 2010, 2(2): 109-111.

[4] I. Hussain and J. Anwar. "A study on contamination of aflatoxin M1 in raw milk in the Punjab province of Pakistan". Food Control,2008, 19(4): 393-395 https://doi.org/10.1016/j.foodcont.2007.04.019

[5] P. Rosi, A. Borsari, G. Lasi, S. Lodi, A. Galanti, A. Fava, S. Girotti E. and Ferri. "Aflatoxin M1 in milk: Reliability of the immunoenzymatic assay". International Dairy Journal, 2007, 17(5): 429-435. https://doi.org/10.1016/j.idairyj.2006.05.003
[6] P.B. Wangikar, P. Dwivedi, N. Sinha, A. K. Sharma and A. G. Telang. "Effects of aflatoxin B1 on embryo fetal development in rabbits". Food and Chemical Toxicology, 2005, 43(4): 607-615. https://doi.org/10.1016/j.fct.2005.01.004

[7] M.Tajkarimi, F. Aliabadi-Sh, A. Salah Nejad, H. Poursoltani, A. A. Motallebi and H. Mahdavi . "Aflatoxin M1 contamination in winter and summer milk in 14 states in Iran". Food Control, 2008, 19(11): 10331036. https://doi.org/10.1016/j.foodcont.2007.10.011

[8] A. C. Manetta, M. Giammarco, L. D. Giuseppe, I. Fusaro, A. Gramenzi, A. Formigoni, G. Vignola, and L. Lambertini. "Distribution of aflatoxin M1 during Grana Padano cheese production from naturally contaminated milk". Food Chemistry,2009, 113(2): 595-599. https://doi.org/10.1016/j.foodchem.2008.07.091

[9] N.Ruangwises, and S. Ruangwises ." Aflatoxin M1 Contamination in Raw Milk within the Central Region of Thailand". Bulletin of environmental contamination and toxicology, 2010, 85(2): 195-198. https://doi.org/10.1007/s00128-010-0056-3

[10] T. Yaroglu, H. H. Oruc, and M. Tayar, M. " Aflatoxin M1 levels in cheese samples from some provinces of Turkey". Food Control, 2005, 16(10): 883-885. https://doi.org/10.1016/j.foodcont.2004.08.001

[11] EC . "Commission Regulation (EC) No 1881/2006 of 19 December 2006 setting maximum levels for certain contami-nants in foodstuffs". In O. J. E. Union. (Ed.), 1881, 2006. Brussels.

[12] S. Basappa, and T. Shantha. "Methods for detoxification of aflatoxins in foods and feeds: A critical appraisal". Journal of food science and technology, 1996, 33(2): 95-107.

[13] K. D. Peltonen, H. S. El-Nezami, S. J. Salminen and J. T. Ahokas. "Binding of aflatoxin B1 by probiotic bacteria". Journal of the Science of Food and Agriculture, 2000, 80(13): 1942-1945. https://doi.org/10.1002/1097-0010(200010)80:13<1942::AIDJSFA741>3.0.CO;2-7

[14] A.E. Yousef, and E. H. Marth. "Use of Ultraviolet Energy to Degrade Aflatoxin M1 in Raw or Heated Milk with and Without Added Peroxide". Journal of dairy science,1986, 69(9): 2243-2247. https://doi.org/10.3168/jds.S0022-0302(86)80663-4

[15] R. Liu, Q. Jin, G. Tao, L. Shan, J. Huang, Y. Liu, X. Wang, W. Mao, W and S. Wang. "Photodegradation kinetics and byproducts identification of the Aflatoxin B1 in aqueous medium by ultra-performance liquid chromatography- quadrupole time-of-flight mass spectrometry". Journal of Mass Spectrometry, 2010, 45(5): 553-559. https://doi.org/10.1002/jms.1741

[16] C. F. Li, and R.L. Bradley Jr. "Degradation of Chlorinated Hydrocarbon Pesticides in Milk and Butteroil by Ultraviolet Energy:. Journal of dairy science, 1996, 52(1): 27-30. https://doi.org/10.3168/jds.S0022-0302(69)86495-7

[17] F. Galvano, V. Galofaro, A. Ritieni,M. Bognanno, A. De Anglis and G. Galvano. "Survey of the occurrence of aflatoxin M1 in dairy products marketed in Italy: second year of observation". Food Addit Contam,2001, 18(7): 644-6. https://doi.org/10.1080/02652030110035381

[18] [H. Mohamadi and M. Alizadeh . "A study of the occurrence of aflatoxin M1 in dairy products marketed in Urmia, Iran". Journal of agriculture science and Technology,2010,12: 579-83.

[19] A. Kamkar, G. Jahed Khaniki and S.A. Alavi SA. "Occurrence of aflatoxin M1 in raw produced in Ardebil of Iran". Iran J Environ Health Science and Engineering , 2011, 8(2): 123-8.

[20] H.C. Tarık, S. Belgin, and K. Özlem. "Aflatoxin M1 contamination in pasteurised milk". Veterinary . Arhiv, 2005, 75(1): 57-65.

[21] A. Zinedinea, L. González-Osnayab, J. M. Sorianob,J. C. Moltób , L. Idrissia and J. Mañesb. "Presence of aflatoxin M1 in pasteurized milk from Morocco".International Journal of Food Microbiology, 2007, 114(1): 25-29. https://doi.org/10.1016/j.ijfoodmicro.2006.11.001

[22] S. Ruangwises, and N. Ruangwises . "Occurrence of aflatoxin M1 in pasteurized milk of the School Milk Project in Thailand". Journal of food Protection, 2009, 72(8): 1761-3. https://doi.org/10.4315/0362-028X-72.8.1761

[23] N. Zhenga,P. Suna, J. Q. Wanga ,Y.P. Zhenb, R. W. Hana, and X. M. Xub. "Occurrence of aflatoxin M1 in UHT milk and pasteurized milk in China market". International Journal of Food Microbiology, 2013, 29(1): 198-201 https://doi.org/10.1016/j.foodcont.2012.06.020 
Int'l Journal of Advances in Chemical Engg., \& Biological Sciences (IJACEBS) Vol. 4, Issue 1 (2017) ISSN 2349-1507 EISSN 2349-1515

[24] Food and Drug Administration (FDA). Guidance for Industry: Action Levels for Poisonous or Deleterious Substances in Human Food and Animal Feed, 2000. 